\title{
SÃO PAULO CIDADE GLOBAL
}

\author{
FIX, MARIANA
}

Prefácio de Flávio Villaça. São Paulo:

Boitempo Editorial, 2007, I96P.

ISBN: 85-7559-089-8

Odette Carvalho de Lima Seabra

\section{Maquetinha DE NOVA YORK}

As semelhanças não são mera coincidência. Ao contrário, respondem às estratégias empresariais bem plantadas no setor sul da cidade de São Paulo. São estratégias ligadas aos fenômenos de internacionalização e financeirização, situadas na confluência dos interesses que movem o moinho satânico do capitalismo em escala global e materializam-se ao longo da marginal do Pinheiros, em São Paulo.

O pleno domínio da várzea, território canadense em passado recente, é, agora, um espaço produzido com atributos de Primeiro Mundo, reluzente segundo a estética pós-moderna, e que nasceu "da noite para o dia". São as grandes torres de escritórios, hotéis, casas de espetáculos, shopping centers que integram uma frente de expansão do circuito imobiliário do capital. Segundo a autora, o ambiente construído desenha um skyline que mimetiza os pólos de negócios nos países centrais.

São megaprojetos os quais, em suas dimensões reduzidas, funcionam como elementos chave para decifrar o fenômeno urbano das últimas décadas. A forma atual de produção e consumo do espaço, as implicações do processo de financeirização, o apartheid social e as relações centro-periferia estão, de alguma forma, condensados nesses edifícios.

Está aqui demonstrado como, no capitalismo, a partir de um certo ponto, o movimento de reprodução ampliada pode racionalizar a irracionalidade de origem, a consistir na imobilização de capital na terra. O ambiente construído nos anos 70 , que configurou a bratklandia, espelha uma modalidade de ação empresarial concebida para tentar neutralizar os efeitos da valorização do espaço, a qual, logicamente, é traduzida no preço das propriedades dos imóveis. Por isso, a lógica do empreendimento monopolista, como nesse caso, consistia em formar estoques de terra urbana pela compra das propriedades modestas dos moradores daquela localidade, as quais, no circuito reprodutivo do capital imobiliário, 
funcionavam como matéria-prima para o capital em processo de valorização. Era uma estratégia que não só visava superar o problema de pagar pela valorização a qual a produção do espaço (no varejo) criava com as inversões de capitais produtivos, como, ao garantir continuidade dos processos em curso, propiciava a captação das rendas diferenciais que iam sendo geradas.

Mas isso foi apenas o início de um processo que galgou etapas muito mais complexas quando a desnacionalização de empresas e a financeirização, como lógica de remuneração dos ativos, começou a presidir os contratos, já, então, sob a vigência do ideário neoliberal. As privatizações de empresas públicas justificavam a presença das empresas estrangeiras e a maior mobilidade do capital, o que fez crescer a demanda por edifícios de escritórios, hotéis, shopping e serviços em geral. Foi criado um espaço tecnológico o qual, como menciona, tem ares de Primeiro Mundo.

Um segundo óbice nesse movimento de produção/valorização era o da incorporação imobiliária, porque a gestão da propriedade parcelada em condomínios funcionava como um entrave à livre circulação do capital. No proprietário estava a personificação da propriedade que constituía, em suas mãos, um bem de raiz cuja mobilidade tanto podia realizar-se por herança como pelo acesso ao mercado, mas em condições que jamais puderam separar a coisa (o bem) da pessoa.

Acontece que essas produções ocorridas no vale do Pinheiros obedeceram a cânones os quais, sem negar a propriedade, aprofundavam as relações capitalistas, transpondo, de certa forma, esse limite. A questão era a de separar a coisa da pessoa, pela adoção de um sistema de crédito destinado a financiar produções comerciais para as quais não existia crédito. O mercado imobiliário estaria, assim, funcionando mais ou menos como um mercado de capitais pela abstração da propriedade, no limite como um capital fictício.

Como os promotores imobiliários tratam como ativo financeiro o imóvel, tornou-se desejável que este deixasse de funcionar como reserva de valor, mas como negócio que gera rendas. Discursos persuasivos passaram a sustentar que o melhor era alugar o imóvel necessário, libertando capital para atividades produtivas. Deu certo, pois a maioria dos imóveis pertence a investidores que alugam para empresas, bancos, multinacionais e outros.

Aproximado ao modelo norte-americano de crédito, o proprietário foi transmutado no proprietário de cotas de participação nos investimentos. A entrada dos fundos de pensões, no financiamento imobiliário, deu-Ihes uma importância central no setor imobiliário. Como substitutos do crédito os fundos foram, então, remunerados com renda (porque se tornaram proprietários) e com valorização patrimonial; era a renda de aluguel dos grandes edifícios de escritórios de alto padrão, os quais são espaços de qualidade estrategicamente planejada para atrair multinacionais; a valorização patrimonial que é, em princípio, a expectativa de ganho pelo conjunto do processo, gera para cada empreendimento, em particular, ganhos que aparecem no portfólio do fundo como renda diferencial.

A renda, nesses termos, é parte da mais valia gerada na produção do espaço; portanto, um mecanismo eficaz de captação de parte da riqueza da sociedade.

Enquanto os lucros derivam de atividades produtivas e, desse modo, reproduzem capital, a renda se situa na esfera da repartição da mais valia, e 
permite formação de capital. Exatamente porque a mais valia social está em relação com o sobreproduto social, os fundos de pensão interessam-se por prédios de alto padrão. Eles possuem um maior potencial de valorização.

Sendo, os fundos de pensão, organizações poderosas da mundialização financeira, agilizam a produção, induzem à padronização dos produtos, aumentam a liquidez que, como conseqüência, estrutura um sistema de agentes interessados na intensificação do uso do solo urbano. As atividades, assim reunidas, movem a cidade como uma máquina de crescimento, no dizer da autora.

Ao final das contas, o deslocamento gerado no movimento especulativo, entre o valor do produto imobiliário (expresso no preço do imóvel) e sua base real, cria a necessidade do ajuste lá adiante; aí então a mercadoria (em salto mortal) em sua realização, revela todo o processo do qual é expressão. Hoje, em certas áreas, a taxa de desocupação de imóveis chega a 70\%, o que demonstra os limites desse processo.

Os fundos chegaram a ter $22 \%$ dos investimentos em imóveis, embora tenha sido uma aliança de fôlego curto. Tanto que hoje parecem estar mais propensos a desmobilizar seus ativos, sob alegação de não existir um referencial (parecido com a taxa básica de juros) de quanto deveria render um ativo imobiliário. Reproduzir um ativo a $12 \%$ a.a. é insignificante.

A atuação dos fundos chegou a estimular a organização de um mercado de ativos financeiros lastreados na produção imobiliária, com a criação dos Fundos de Investimentos Imobiliários (FII), regulamentados em 1993, cuja finalidade é operar com o varejo.

Em meados dos anos 90 o Brasil passou a ser um dos maiores receptores de investimentos estrangeiros diretos no mundo. No entanto, a desnacionalização da economia produziu mudanças no mercado imobiliário muito menores que em outros setores. Instalaram-se, aqui, empresas de consultoria para atender seus clientes mundiais.

A vinda de empresas estrangeiras aumentou a demanda de imóveis de alto padrão. Essas empresas visavam à recriação de ambientes dos quais dispunham em seus países de origem. É com esse sentido que acabavam abrindo espaço para empresas de consultoria atenderem clientes mundiais. De modo geral, essas empresas operam com corretagem de escritórios e de imóveis industriais, serviços financeiros, consultoria imobiliária, gerenciamento de ativos, serviços corporativos, avaliação e pesquisa, o movimento no sentido da formação de joint ventures.

Mesmo contando com a presença de grandes investidores (George Soros, Morgan Stanley, Trust Company of the West, entre outras), o processo de internacionalização, com investimento direto no setor imobiliário, é incipiente no Brasil. A maior parte das empresas que atuam na produção das grandes torres é, ainda, nacional.

O perfil das empresas locatárias revela uma internacionalização da cultura, uma cultura globalizada que veio também das mãos das empresas nacionais e dos profissionais brasileiros os quais procuram reproduzir o modelo americano.

Mas, para a autora, toda questão é: tais produções correspondem ao modelo ancorado em estabilização monetária a qualquer custo, desnacionalização, desindustrialização com expansão dos circuitos de valorização patrimonial e 
financeira. E, sobretudo, em um país periférico, combinando elementos de um processo de homogeneização com aspectos específicos próprios de nossa formação, resta o bizarro, como são os territórios que funcionam como enclaves urbanos, tal como acontece com essas produções na marginal do Pinheiros. Ali estão inscrições territoriais com limites bem precisos, quase fronteiras a separem a parte do todo. A integração desse espaço à economia global, em nome da internacionalização, funciona como separação, como fragmentação do ponto de vista da sociedade local.

Quem diria que a previdência privada (é isso que são os fundos de pensões), sucedânea de nossa velha e sempre ameaçada aposentadoria, teria, no movimento geral de reprodução capitalista, funções de agilizar os ciclos de realização do capital imobiliário à escala global.

Fruto de uma pesquisa primorosa em todos os seus detalhes, esse texto traz informações muito relevantes e mesmo até então desconhecidas, para discutir a lógica dessa urbanização, bem como de seus limites. Contém uma lição de método de investigação e de exposição de resultados. Sua qualidade deriva da atitude teórica clara e coerentemente articulada no objeto.

Esse livro, que interessa ao conhecimento de São Paulo, desta metrópole semi-periférica com um "Primeiro Mundo incrustado", ao tratar da produção imobiliária mais que moderna da marginal do Pinheiros, desmistifica essa incrustação. Em vista disso, interessa a todos que queiram compreender um pouco mais desse mundo em que nos é dado viver.

\section{Odette Carvalho de Lima Seabra}

Professora do Departamento de Geografia da FFLCH-USP

e-mail: odseabra@usp.br 